\title{
Religion and Education in Romania: Social Mobilization and the "Shadow" of the European Court of Human Rights $^{1}$
}

\author{
Mihai Popa
}

Department 'Law and Anthropology', Max Planck Institute for Social Anthropology

\section{Liviu Andreescu}

University of Bucharest

\begin{abstract}
In this article, we discuss the relation between the European Court of Human Rights (ECtHR) and its jurisprudence and social mobilizations around the place of religion in the society. We focus on the struggles to define the intersection of religion and public education in Romania after the fall of communism. We show that secularist and counter-secularist civil society activists contending for the place of religion in public education in this country have made strategic use of the ECtHR and its case law, both in legal battles and in debates within the national public sphere. We argue that, since references to the ECtHR and its jurisprudence can be used in discursive battles as a form of symbolic "capital", the strategies of mobilizing actors are at times more important than the strict doctrinal content of the ECtHR's judgments for understanding if and how the ECtHR's "shadow" is cast over religion-related mobilizations.
\end{abstract}

\section{INTRODUCTION}

We engage here an object of intense academic scrutiny: the European Court of Human Rights (hereafter "ECtHR", "the European Court", or simply "the Court"), arguably the world's most influential human rights

Address correspondence and reprint requests to: Mihai Popa, Max Planck Institute for Social Anthropology, Advokatenweg 36, 06114, Halle/ Saale, Germany. E-mail: popa@eth.mpg.de 
tribunal (Durham and Kirkham 2016). We share past analyses' preoccupation with the Court's religion-related jurisprudence, mainly characterized until now as having a secularizing influence (e.g., Evans and Petkoff 2008, Gülalp 2010, Koenig 2015, Ringelheim 2017; compare Mancini 2009). This already developed body of literature focuses on the doctrinal substance of the Court's judgments and their potential "direct" judicial and administrative impact. In contrast, our analysis aims to contribute to the study of the broader, comparatively less examined, "indirect" effects of the Court's jurisprudence (Fokas 2015). We show that the Court's jurisprudence plays a part in religion-related mobilizations in post-communist Romania. Here, normative statements from the Court's judgments are called upon both by those seeking a reduced role for religion in the society and policy-making, as well as by those defending a prominent role. The Court's "shadow" expands beyond the legal arena, especially when both secularist and counter-secularist activists engage the language of "rights" to argue their claims in the public sphere. We argue that, in order to understand how (and to what effect) the Court's "shadow" is cast over social mobilizations around religion's place in the society, we need to look beyond the doctrinal substance of the Court's decisions to the uses that social actors make of them in (counter-)secularist conflicts carried out both within and beyond the legal arena.

Our inquiry started from the following main questions: "who are the social actors who pay attention to the Court's religion-related decisions", and "how are these actors' religion-related mobilizations connected to the decisions' content?" In other words, for whom and in which ways does the Court become relevant for social mobilization around the place of religion in the society? ${ }^{2}$

Issues concerning the "religion-and-education" nexus-we focus here on religious education classes, religious symbols in public schools, and sex education-have been central topics of contention in the redefinition of religion-state relations in Romania after 1990. They are at the core of this analysis because they serve perfectly to illustrate both the development of national-level secularist and counter-secularist activism and the appeal to the Court therein. While our analysis focuses on the religionand-education issues, we occasionally look also beyond this arena of contention, at other topics that have stoked (counter-)secularist mobilizations referencing the Court and its case law (such as the issue of the legal protection of same-sex couples). In addition, we describe not only the national-level dynamics of contention, but also some of the transnational dynamics that have influenced the former. We show that the civil society 
activists have played crucial roles in shaping the Court's relevance for religion-related mobilizations by linking national and transnational mobilization dynamics and by shifting between distinct social fields, especially between the legal arena and the public sphere.

In the second section below, we introduce our theoretical perspective and present our methodology. In the third section, we provide a historical overview of mobilizations around religion-and-education issues, and bring to the fore the most prominent actors involved therein. In the fourth and fifth sections we point to how actors involved in religion-related mobilizations developed and maintained an interest in the European Court's decisions. In the concluding section, we emphasize that, in order to understand the relevance of the Court for religion-related mobilizations, we need to pay attention to the strategic uses that activists make of the Court's jurisprudence.

\section{(COUNTER-)SECULARIZATION IN THE "SHADOW" OF THE COURT: ACTORS, STAKES, AND THE COURT'S PLACE IN THE POLITICAL OPPORTUNITY STRUCTURE}

Romania provides a particularly fruitful context for studying the relation between the Court's jurisprudence and (counter-)secularist mobilizations. First, the country has been the site of a dynamic resurgence of religious influence on state policy after the fall of communism in 1989. In its attempts to assert itself as the "national church" (Romocea 2011), the majority Romanian Orthodox Church (hereafter simply "Orthodox Church") catalyzed limitations on the religious freedom of minority communities through the intervention of state authorities (some of which also triggered complaints at the Court; see Popa and Andreescu 2017 for an updated overview). The Orthodox Church's role is also prominent in the counter-secularist mobilizations we analyze here. Second, while it was witnessing the reinvigoration of institutionalized religion after communism, Romania was undergoing the complex political, economic, and social process of integration into the European Union (EU, joined in 2007), preceded by the developments that resulted in the Council of Europe membership (joined in 1994). While these processes are themselves relevant for (de-)secularization dynamics (on EU membership see, e.g., Byrnes and Katzenstein 2006), we mention them here particularly for their significance regarding the Court's influence.

It was especially during the process of EU integration that the Romanian post-communist state was hard pressed to comply with the 
European human rights standards (a component of the EU acquis communautaire). This element distinguishes Romania's relation to the Court (via EU mechanisms) from that of countries like Italy (a founding member of the EU) or Turkey (currently trapped in a stalemate with respect to EU accession negotiations). Until present (writing in December 2017), the Court has become a visible and legitimate component of the "political opportunity structure" (Koopmans 1999) relevant for citizen-state interaction in Romania. To this fact attest both the high number of cases from Romania pending in Strasbourg (with a correspondingly high track record of violations) ${ }^{3}$ and recent survey data on Romanians' perceptions of the Court. ${ }^{4}$ The Council of Europe's Court scores close in public levels of perceived trustworthiness to the institutions of the EU, ${ }^{5}$ with which it is at times symbolically conflated (as "European" institutions). As our analysis indicates, these public perceptions find correspondence in the present-day referencing of the Court and its case law not only in court rooms, but also in debates in the national public sphere.

To start zooming in on the subject of our inquiry, in the following subsection, we link conceptually the Court's place in the political opportunity structure for citizen action with its relevance for (counter-)secularist mobilizations in Romania; we then present our data gathering methodology.

\section{Theoretical Framework}

Socio-legal scholars have pointed out that the courts of law produce effects not only through their rulings in particular cases, but also through the meanings that these rulings acquire in the society more generally (Galanter 1983; McCann 2004). Drawing on this insight, it is important to distinguish between the strictly administrative ("direct") effects of court rulings and their broadly social effects ("indirect", or "radiating", to use Marc Galanter's term). For the purpose of analyzing how social actors use court rulings to bring changes in the society and state policy, we find it useful to think of these rulings' effects as taking place across social "fields" (Bourdieu and Wacquant 1992; Fligstein and McAdam 2011). The legal arena and the public sphere are the two fields (see, e.g., Bourdieu 1977, Fraser 1990, Calhoun 2010) central to our analysis.

Madsen (2007) and more recently Koenig (2015) have made the case for regarding the European Court as an institution embedded in a "transnational legal field". Both authors emphasized that, in time, the Court has taken a more independent stance in relation to the interests of the Council 
of Europe member states in interpreting the European Convention on Human Rights (ECHR). This has led, in Koenig's (2015) view, to the Court becoming an "agent of secularization" (57) in Europe, among others by providing "authoritative repertoires of justification" (72) for those contesting states' privileging of religious majorities. In his analysis, Koenig refers to a variety of religion-related cases, including Dahlab v. Switzerland (2001), Refah Partisi v. Turkey (2003), S,ahin v. Turkey (2005), Hasan and Eylem Zengin v. Turkey (2007), and Lautsi v. Italy (2011) (see the brief descriptions of these and additional cases relevant for our analysis in Table 2 of the Appendix ${ }^{6}$ ). Expanding on Koenig's (2015) remarks, we view recent Court jurisprudence concerning the legal protection of same-sex couples (e.g., Oliari and Others v. Italy [2015]) as similarly providing repertoires of justification for those pressing for a lesser influence of religious views on family law and policy.

If the Court offers chances of litigation success to the "secularists", it becomes relevant also for the corresponding opposing movement (Meyer and Staggenborg 1996). It counts as a source of "opportunities"understood as both "possibilities" and "threats" (Koopmans 1999, 96) that can influence the mobilization of both secularist and counter-secularist activists. We draw on these insights in our analysis, additionally looking beyond the confines of the juridical field for possible uses of the Court's jurisprudence.

Our emphasis on how social actors use the Court's jurisprudence in an arena of religion-related conflict brings us close to the recent analyses of (counter-)secularization processes. With Smith (2003) and Karpov (2010), among others, we consider that "secularization" is most fruitfully analyzed from the viewpoint of the processes of social conflict that oppose actors with different interests concerning the place of religion in the society (rather than as the agent-less corollary of processes of modernization). Like these authors, we emphasize actors' strategies and the resources they draw on, including the symbolic resources (such as knowledge of the Court's case law) deployed in debates in the national public sphere.

Conceptualized by Jürgen Habermas as a neutral space for reasoned dialogue mediating between state action and citizen will (Habermas [1962] 1991), the "public sphere" has recently been approached from analytical perspectives that emphasize inequality and domination (e.g., Fraser 1990, Calhoun 2010). Fraser (1990), for instance, has insisted that actors endowed with different levels of power struggle to define legitimate discourses within the national public sphere. Thus, discursive practices are not simply neutral, rational, and oriented toward the common good (as 
in the original Habermasian normative formulation), but practices of social "distinction" expressing and reinforcing, rather than suspending, status inequalities (Fraser 1990, 60). Also emphasizing conflict and inequality, Calhoun (2010) more recently suggested to look at the public sphere itself as a "field" in Bourdieu's sense, and to take into account the inequalities that influence its dynamics, including the distribution of different forms of "capital" among participants.

It is precisely as a "species of capital" (Bourdieu and Wacquant 1992, 98) that we can best conceive of the knowledge of the Court's case law among the actors involved in the (counter-)secularist mobilizations analyzed here. As Bourdieu pointed out,

\begin{abstract}
the value of a species of capital (e.g., knowledge of Greek or of integral calculus) hinges on the existence of a game, of a field in which this competency can be employed: a species of capital is what is efficacious in a given field, both as a weapon and as a stake of struggle, that which allows its possessors to wield a power, an influence, and thus to exist, in the field under consideration, instead of being considered a negligible quantity (1992, 98, emphasis in the original).
\end{abstract}

Knowledge of the Court's case law, like knowledge of Greek in the quotation above, is relevant in present-day Romania in the juridical field. Judges and prosecutors are both regularly trained in the Court's case law and formally evaluated according to the extent to which their decisions make reference to the ECtHR. Knowledge of the Court's jurisprudence functions as a marker of distinction for lawyers as well, especially in a context in which appropriating this knowledge depends much more on individual skill (knowledge of English and French, the Court's official languages) and professional experience than on formal training. ${ }^{7}$ In addition, knowledge of the Court's case law is also relevant in the public sphere, where various actors (jurists and non-jurists alike) invoke the ECtHR as a source of ultimate justice or of authoritative pronouncements regarding respect for human rights. As we show below, both secularist and counter-secularist activists learn about the Court, pay attention to its case law, and invoke it in both legal proceedings and in public debates. This theoretical perspective allows us to "de-center" (Galanter 1983) the analysis of the Court's "shadow" over religion-related mobilizations, and to observe that the actors' discursive strategies are at times more important than the strict doctrinal content of the Court's judgments for understanding if and how the latter are referenced. 


\section{Methodology}

The empirical material on which this analysis draws stems mainly from the first author's field research carried out between April 2015 and June 2017. The research was carried out within the framework of the ERC-funded program "Directions in Religious Pluralism in Europe: Examining Grassroots Mobilisations in the Shadow of European Court of Human Rights Religious Freedom Jurisprudence" (Grassrootsmobilise) and involved a multi-method approach, which included: (1) textual analysis of materials from online mass media sources, as well as from administrative texts and court case files; (2) interviews with individuals selected for the project's different religion-related research themes (e.g., the legal status-religious freedom nexus, analyzed in Popa and Andreescu 2017); (3) observation of discursive practices in public events. The main aim of the larger field research was to take note of social actors' awareness of the Court and their use of references to the Court and its case law in religion-related mobilizations.

Apart from textual sources and observation notes, the analysis presented in this article draws on a subsample of Grassrootsmobilise interviews (see Table 1 in the Appendix). In the wider research project, interviews were mostly carried out in the capital Bucharest (41 out of a total of 48) and mostly in person (with three exceptions, where the interviews were carried out by phone) and in Romanian (with two exceptions, where the language of the interview was English). The sampling was purposeful, aiming to obtain both "intensity" from information-rich cases and "variation" to enable the identification of patterns (Patton 2001, 108-109). In the present analysis, we focused our attention on actors (either interviewed or observed in public debates and events) following a field logic, paying attention especially to those most prominent for the processes under scrutiny (Bourdieu and Wacquant 1992, 243).

In the analysis below, we draw directly on a subset of 14 semistructured interviews and follow-up discussions with 13 activists from eight NGOs that have cooperated on various secularist mobilizations (including those we discuss here) ${ }^{8}$ three interviews and follow-up discussions with three activists from as many counter-secularist NGOs; ${ }^{9}$ six interviews with persons working in five religious organizations operating at national level; ${ }^{10}$ one interview with an expert on religious education from the Institute of Education Sciences (a direct subordinate to the Ministry of Education); and one with a member of the National Council Combating Discrimination. While we zoom in on just a few activists 
and organizations, our general argument is built on the data collected from the subset of interviews indicated above, as well as on the observational and textual data gathered during the research.

\section{RELIGION IN ROMANIAN PUBLIC EDUCATION: A HISTORICAL OVERVIEW AND OUTLINE OF THE STRATEGIC ACTION FIELD}

Mobilization around religion's presence in public education ${ }^{11}$ in Romania since 1990 has involved an array of individuals and organizations, which has stabilized in time with respect to its composition and strategic repertoire. What other authors have called a "strategic action field" gradually arose, meaning an arena of conflict populated by actors aware of who their friends and foes are, what is at stake, and what strategies are possible and legitimate (see Fligstein and McAdam 2011: 3-5). Addressing state officials, stoking debate in the public sphere through open letters, responding in the mass media to adversaries' challenges, litigating in courtsthese strategies are all part and parcel of the conflicts reviewed in this section. We illustrate contention dynamics by focusing on three main themes: religious education classes in public schools, the presence of religious symbols on classroom walls, and the controversy over including sex education in the school curriculum.

\section{Religious Education}

The presence or absence of religious education classes as well as their content and who teaches them have been topics of contention in very diverse times and places for groups interested in influencing the dynamics of secularization (see, e.g., Jackson 1992 on the UK, Lisovskaya 2016 on the Russian Federation). Romania in the past decades has been no exception, especially as educational standards concerning professionalism, inclusion, and pluralism-such as those in OSCE's Toledo Guiding Principles on teaching about religion and beliefs ${ }^{12}$ - have only gradually made their way into the curriculum.

For over two decades, religious education classes (hereafter "RE" or "Religion") have been offered in Romanian public schools on a confessional basis as "part of the core curriculum", a phrase signaling that schools are obliged to offer the course. This arrangement is open to all of the 18 officially recognized denominations, but not to other religious communities. ${ }^{13}$ Enrollment in RE has been made, for a couple of years 
already, based on parents' request ("opt-in"). Pupils taking the course, either within the school or, alternatively, in the communities, receive a grade that contributes to their general average; those not taking it receive no grade. Representatives of left out groups would prefer (as pointed out to us) ${ }^{14}$ a class about the "history of religions" ("teaching about religion" as recommended in the Toledo Principles) instead of the catechetic education currently offered ("teaching religion").

The subject matter "Religion" was introduced in public schools immediately after the collapse of the communist regime through the efforts of the majority Orthodox Church, which signed a formal protocol with the Ministry of Education for this purpose in 1990. The move clearly signaled an emergent dynamic of de-secularization, one that other authors have characterized as "from above" (Karpov 2010, see also Lisovskaya and Karpov 2010 on religious education in Russia). The 1990 protocol made confessional religious instruction part of the public educational offer and "framed subsequent debates on religious education in Romania" (Stan and Turcescu 2007, 153).

While the Orthodox Church took the initiative and laid the foundation stone for catechetic religious instruction in public schools, this arrangement opened in time to other recognized religious denominations. Our interviews with representatives of minority religious denominations indicated that the formal opening (through the 1995 national Law on Education) for religious minorities to teach "Religion" was accompanied by practical problems, such as the difficulty of organizing on school premises study groups of at least seven pupils, or the evaluation of teaching quality predominantly by Orthodox "Religion" teachers. In time, the strategies of minority religious organizations without strong local concentrations of believers converged toward abandoning the offering of catechetic education through the public school system. ${ }^{15}$ In contrast, the Orthodox Church stabilized as the most active religious organization defending the "Religion" class.

The Orthodox Church's strong influence on religious education was met by adamant criticism coming from the activists from the secularist camp of the Romanian civil society (see, e.g., the contributions to the public debate comprised in Enache 2007). In time, the latter managed to pressure state authorities in charge of supervising the "Religion" curricula and textbooks to pay more attention to sensitive issues such as inter-confessional relations and discrimination. ${ }^{16}$

As mentioned above, the array of organizations and individuals involved in mobilizations around religion-and-education issues has 
stabilized in time with respect to its composition. On the secularist side, two long-time human rights activists have arguably become the public face of recent mobilizations on religious education. These are Remus Cernea and Emil Moise, formerly both members of the Association Solidarity for Freedom of Conscience (an NGO of which Moise is still the president). The two activists have been prominently involved in the mass media debates following the 2014 Constitutional Court decision that changed the system of registration in the "Religion" class from an "opt-out" procedure (pupils were enrolled by default, but they or their legal guardians could ask for an exemption) to an "opt-in" procedure (requests must first be filed before pupils are enrolled in the class). While Cernea has been at the forefront of also other mobilization themes (such as the legal protection of same-sex couples) ${ }^{17}$ Moise has specialized in litigation concerning the place of religion in education.

Moise's 2014 successful litigation at the Constitutional Court that changed the enrollment procedure in the "Religion" class came after several defeats in the legal field: in 2012, also at the Constitutional Court (on the same issue of enrollment), and in 2008, at the High Court of Cassation and Justice (on the presence of Orthodox religious symbols in schools, to which we turn in the next sub-section).

The 2014 Constitutional Court ruling sparked intense debates in the national public sphere between roughly November 2014 (when the decision was issued) and March 2015 (the legal deadline set for the filing of requests in the new enrollment system). Televised debates provided a good opportunity to observe the composition of the conflict arena, as well as the position-takings and discursive strategies of the contending individuals and organizations. In one such television show, aired by the national-coverage channel Realitatea TV on February 26, 2015, Remus Cernea represented the secularist camp (Emil Moise was interviewed by telephone). Among the other guests (mostly defending the previous "opt-out" system of enrollment in the "Religion" class) were a former minister of Education, the president of the newly founded Association "Parents for the Religion Class" (APOR, presented in more detail below) and the administrative vicar of the Orthodox Church's Patriarchate.

Interesting for our analysis was especially the exchange between Cernea and the vicar. While the former defined the problem of default enrollment as one of "rights" infringement (especially for students from minority religious communities), the latter responded promptly by drawing on formulations from national legal texts. The vicar emphasized that he was speaking in the debate "to a great extent as a jurist" and less as an 
Orthodox priest. While he did not invoke the jurisprudence of the Court to support his arguments (as he had done in other public interventions), the vicar noted that the idea of "Europe" that guided secularist activists seeking to push religion "to the private space" was mistaken, and that European integration was not synonymous with the rejection of (national, Orthodox) "tradition".

We will present again below episodes in which jurists and juridical expertise come to the fore in public debates in the arena of conflict that we analyze. This dynamic is related to the presence of "rights" discourse in public debates (stoked by secularist activists), which creates the wider discursive context for referencing the Court and its case law.

As already pointed out, another guest in the above-mentioned television show was the president of the countrywide association APOR, founded under the spiritual guidance of the Orthodox Church's Patriarch in the aftermath of the 2014 Constitutional Court decision. The organization was instrumental in mobilizing large numbers of parents to file requests for their children to take the "Religion" class before the March 2015 enrollment deadline. Since then, it too became a stable organizational actor of the counter-secularist frontline on religion-and-education issues and, as we show later, it organized the participation of individuals with juridical expertise in counter-secularist mobilizations beyond the religionand-education arena as well.

\section{The Display of Religious Symbols in Public Schools}

The same Emil Moise introduced above waged, primarily between 2006 and 2008, a battle against the unregulated display of Orthodox religious icons on the walls of public schools. He did so in domestic courts as well as at the National Council Combating Discrimination (hereafter simply "anti-discrimination Council"). Because we return to Moise's litigation later below, we dwell in this section on the anti-discrimination Council and on the most prominent protagonists of the countermobilization that was sparked by the icons' case.

As mentioned before, the process of EU accession was important for the dynamics of (de-)secularization and the Court's case law referencing in Romania. The anti-discrimination Council, established in 2000 in connection with the adoption of EU anti-discrimination legislation, is an illustrative example of how the EU accession process favored the secularist cause through the building of institutions particularly mindful of European legal 
standards. Since its establishment, the anti-discrimination Council has been headed by a College of Directors nominated by parliamentary political parties but influenced by representatives of the human rights (and secularist) sector of the Romanian civil society. The latter have proposed members from within their ranks and have evaluated political parties' nominees. Enjoying an autonomy safeguarded through direct European Commission monitoring (in the pre-accession period), the anti-discrimination Council not only became an active user of the Court's case law in its public judgments, but also a "friend" of the secularist cause - often in support of religious minorities and in opposition to the majority Orthodox Church. ${ }^{18}$

In 2006, the Council, drawing also on the Court's case law, answered Moise's complaint against the display of Orthodox icons in schools by saying that, indeed, it was "contrary to the principle of the religious neutrality of the state". The Council asked the Ministry of Education to issue regulations to ensure that public schools display religious icons only during "Religion" classes. ${ }^{19}$ The decision was contested in civil courts by the Ministry of Education and by the Orthodox civil society activists (which we present below), initially confirmed by an appellate court, but eventually overturned by the High Court of Cassation and Justice.

Important in the economy of the conflict that ensued after the antidiscrimination Council's icons decision was not only the reaction of the Orthodox Church (active across the themes we are concerned with here), but also that of the Orthodox civil society organizations. While an entire platform of protest ensued, one NGO remained particularly active in the contention arena analyzed here. The Bucharest branch of the pro-life Association "PRO VITA for the Born and the Unborn" (hereafter "ProVita-Bucharest") intervened not only in the public debates, but also in the legal battle against the decision on the removal of Orthodox icons from schools. Because it is one of the stable actors in the field under scrutiny here, we dwell for a moment on this organization before moving on to the theme of sex education (on which ProVita-Bucharest has also been very active).

ProVita-Bucharest was founded in 2005 and, while it gathers mainly Orthodox activists, it is not subordinated to the Orthodox Church (differently from APOR). As one of this NGO's representatives shared with us in an interview, the organization does not prioritize litigation, but entered the fight in the juridical field during the icons' case in order to defend the display of icons in public schools, viewed as "one of our rights". The NGO has since maintained an interest in legal battles and even 
submitted a third party intervention in the proceedings of the Lautsi v. Italy (2011) case at the Court. ${ }^{20}$

Our ProVita-Bucharest interviewee (to whom we return again below) was one of the most ECtHR-savvy interviewees working within a counter-secularist NGO. This person was also an active contributor to the pro-life forum Cultura Vieții (Eng. Culture of Life; www.culturavie tii.ro), an online platform that presents (in Romanian) analyses of reproductive rights and right-to-life issues, including on the relevance of the Court's decisions to the pro-life and pro-family agendas. ${ }^{21}$ The forum also contains many contributions concerning the negative effects of sex education, the third topic of contention we overview here.

\section{Sex Education}

The theme of mandatory sex education became a public issue much later than religious education. It was brought to the attention of the Ministry of Education by an array of activists and NGOs, most actively those focusing on reproductive and LGBT rights, but also on state secularism (e.g., the Secular Humanist Association from Romania-ASUR). ${ }^{22}$ Likely due to the traumatic character of the Ceaușescu regime's pro-natalist policies (see, e.g., Kligman 1998), for a while after 1990, some churches avoided clear positions on the unpopular option of limiting reproductive rights (see Stan and Turcescu 2005, 300, on the stance of the Orthodox Church on abortion). NGOs in the pro-life movement, such as ProVitaBucharest, have been comparatively more emphatic in their countermobilizations. Their campaigns against efforts by the Ministry of Education to introduce an (initially optional) sex education curriculum around the mid-2000s brought together conservative civil society organizations and religious groups in concerted, forceful criticism. One NGO particularly active on sex education and sexual mores in general is the Alliance of Families from Romania (AFR). ${ }^{23}$ As an important player in the field that interests us, and one stimulating attention to the Court among counter-secularist activists, we briefly dwell on its story.

AFR was born in the aftermath of an unsuccessful mobilization to change the definition of "marriage" in the Romanian Constitution so as to explicitly denote "the union between a man and a woman" (rather than "spouses", as in the current form). In Romania, a referendum to change the Constitution can be started through a "citizen initiative", which needs at least 500,000 signatures of support from at least half the 
country's 41 counties and the capital Bucharest. The initiative started in 2006 failed to reach these goals, but the involved activists formed AFR in its aftermath (ProVita-Bucharest is itself one of the founding members of AFR, attesting to the close cooperation of the two NGOs). In addition, links established around the time of the 2006 mobilization to Alliance Defending Freedom, an international conservative NGO specialized in legal counseling (see Bob 2012, 100-1), are still maintained by AFR. When the mobilization campaign was restarted in 2015 by the same core group of activists (and this time met the technical criteria for organizing a referendum), a heated debate that involved both national and transnational activists with juridical expertise was sparked in the national public sphere (a point to which we return below).

AFR, together with ProVita-Bucharest and the newly established APOR, became recently the most prominent NGOs mobilizing in the arena of conflict around sex education. While they sometimes gather support signatures from many other NGOs, these counter-secularist "front liners" are the prime movers behind actions such as open letters to state authorities and communiqués. ${ }^{24}$ In their strategy of gathering broader support for their public interventions, they are not much different from their secularist counterparts, ${ }^{25}$ just as they are not different in leveraging publicly the judgments of the Court. In the following two sections, we indicate how the practice of Court referencing by secularist and counter-secularist actors has become one element of an accepted repertoire of actions in both legal battle and public debate. Grounded in the field-theoretical perspective, our account is relational, in that it explains individual actors' strategies in connection to a wider set of "allies" and "adversaries".

\section{POST-COMMUNIST HUMAN RIGHTS LITIGATION AND THE COURT'S RELEVANCE FOR SECULARIST ACTIVISTS}

The secularist activist Emil Moise explained to us in an interview that he had built his icons display litigation by drawing on ECHR provisions and on the Court's case law because the latter had been his envisaged final destination. He conceded having felt "envious" when hearing about the Chamber judgment in the Lautsi case, which supported the removal of crucifixes from Italian classrooms, since he had hoped to be the first to win such a case at the Court. The subsequent overturning of that decision by the Grand Chamber did not demobilize Moise, who went ahead with his own complaint at the Court, considering that the Romanian icons' 
case was different from the Italian crucifixes' one. His application was eventually unsuccessful.

When they go to court, activists such as Moise participate both in the national legal field and in the "transnational legal field" of which the Court (Madsen 2007; Koenig 2015) as well as other litigants, such as the plaintiff Soile Lautsi, are a part. Below we indicate how it is possible to understand Moise's and other secularist activists' enduring interest in the Court's jurisprudence in relation both to involvement in legal disputes and to strategies of contention in the public sphere.

Analysts of Western aid to Eastern Europe have pointed out that, apart from money, post-communist Eastern Europe was also the recipient of models of organizing civil society (see, e.g., Sampson 1996). Observing the field of human rights NGOs in Romania, some analysts have noted the predominance of "discourses of professionalism and managerialism" and of "an agenda of international lobbying, rather than one of social services" (Stychin 2003, 133). We know from both personal experience (especially that of the second author) as well as from our interviews with activists from the secularist camp of the Romanian civil society that this sector has received in time significant funding for strategic litigation from international donors (e.g., the Open Society Foundation). While we do not imply that litigation funding was mainly responsible for activists' attention to the Court, we do think it has made a difference in rendering the Court more effectively a mobilization option (Koopmans 1999).

Until the present time several NGOs joining secularist mobilizations have also been successful in their adjacent agendas regarding the protection of vulnerable groups in post-communist Romania. NGOs such as the Association for the Defense of Human Rights in Romania-Helsinki Committee (APADOR-CH), the LGBT rights organization ACCEPT, and the Centre for Legal Resources (CRJ) have all litigated and won cases at the Court against the Romanian state. These cases revolved around the protection of the rights of religious and ethnic minorities (APADOR-CH), sexual minorities (ACCEPT), and institutionalized persons (CRJ). This experience has surely played a role in making the Court a relevant forum for human rights and secularist activists. Emil Moise himself submitted a complaint to the Court with support from his associates in the human rights camp. But we would suggest that the relevance of the Court in the Romanian context gradually became more independent of litigation at the Court per se.

At a conference with the topic "Balancing freedom of expression with the principle of equality and non-discrimination" organized in Bucharest 
at the end of May 2015 by several human rights NGOs and attended by the first author, the case law of the Court featured prominently in the discussions. Emil Moise did not take part in this event, but some of his organizational and individual associates were among the organizers and speakers. The conference included representatives from the above-mentioned NGOs APADOR-CH, ACCEPT, and CRJ, all experienced in litigation at the Court. But while references to the Court's case law were frequent, there were also signs in the discussions that litigation was not necessarily the main aim of the participants making these references. At one point, when the representative of the anti-discrimination Council suggested to the activists present at the conference to litigate in Strasbourg in order to improve the Council's decisions if the domestic courts would fail to do so, one activist from CRJ retorted vehemently that litigation at the Court was "expensive" and that things should be resolved by the national institutions.

Litigating in Strasbourg has lost in both feasibility and importance for the human rights activists after Romania's accession to the EU. Several activists pointed to us that, after this point in time, strategic litigation funds were more difficult to find (e.g., the Open Society Foundation is still an important donor, though funding has been reduced). In addition, activists can now also turn to the Court of Justice of the European Union (CJEU) for cases solvable through appeal to EU legislation. This was the path recently chosen by LGBT rights activists, who reached the CJEU with the case of a same-sex couple married in Belgium, in which the main complaint revolved around the Romanian authorities' refusal to grant one spouse a residence permit qua member of the other spouse's family (Coman case C-673/16, currently pending before the CJEU). ${ }^{26}$ Our interviews show, however, that human rights/secularist activists still maintain an active interest in the Court. ${ }^{27}$ Even in the absence of a clear aim to litigate in Strasbourg, references to the Court are very much relevant for legal battles in Romanian courts or for arguments in public debates.

To refer back to Fraser's (1990) point, knowledge of the Court's case law will likely continue to play a role as a marker of activist "distinction" in the Romanian public sphere. For instance, in one televised debate, Emil Moise himself underscored the importance of his expertise and the strength of his argumentation by pointing to the energy devoted to the study of "the European Court's case law" (in addition to documents from other supranational institutions). ${ }^{28}$ As we show in the next section, counter-secularist activists today act in similar fashion, after having learned from their secularist adversaries and from their counter-secularist allies. 


\section{COUNTER-SECULARIST POSITION-TAKINGS DRAWING ON THE COURT AND ITS CASE LAW}

The process of integration into wider European structures after the fall of communism has provided human rights and secularist activists both with political leverage (illustrated, for instance, by the activity of the antidiscrimination Council) and with a symbolic advantage. The fact that "European" institutions have been and still are trusted by the majority of Romanian citizens much more than state institutions only made it easier, in our view, for these activists to import into public debates arguments based on European legal instruments. Some conservative public intellectuals have criticized the deployment of this discursive strategy for secularist goals as "fraud" and accused secularist activists of "blackmailing" Romanian "corrupt and opportunistic (state) institutions with 'human rights' and 'European legislation'". ${ }^{29}$ Such criticisms may resonate with many in the counter-secularist camp of Romanian civil society. Still, in time an increasingly visible segment of the latter has come to accept the "human rights" idiom. By engaging in competition for symbolic advantage within the same "comprehensive public" as their opponents (Fraser 1990, 66-68), these counter-secularist activists have gradually come to embrace the task of "translating" (Habermas 2008) religion-based claims into the frame of legal argumentation. By strengthening the salience of juridical and "rights" pronouncements in the conflict arena we analyze here, these activists have contributed themselves to discourse secularization in the Romanian public sphere.

As social movement scholars have pointed out, when activists on opposing sides participate in the same contention arenas, they are likely to adapt to one another's strategies and repertoires of action (Meyer and Staggenborg 1996, 1649-1650). Such dynamics came up in our interviews with representatives of ProVita-Bucharest and AFR. For instance, our interviewee from ProVita-Bucharest told us that he became interested in the Court when the secularists, pressing for the removal of icons from schools, threatened to take the case to the Court in Strasbourg if domestic courts would overturn the anti-discrimination Council's decision. As our interviewee intimated,

They [the secularists] kept saying that they would take the case to the ECtHR. [...]For us, [the ECtHR] was relevant, of course, because we thought that if we lose here, we would go to the ECtHR [...] with a request for intervention. 
A similar dynamic was reflected in the account of our AFR interviewee, who confided that his interest in the case law of the Court was aroused by its frequent referencing in the amici curiae letters submitted to the Constitutional Court by the LGBT rights activists who had opposed the 2006 initiative to change the Constitution.

While the accounts of these two actors do not enable us to assert with certainty that 2006 represented a turning point in stimulating interest in the Court among counter-secularist activists in Romania, additional evidence supports our observation that the "rights" discourse, legal argumentation, and Court referencing gained serious momentum in this camp, especially after the middle of the previous decade.

After the above-mentioned episodes, both our interviewees developed stable connections to jurists from the European Centre for Law and Justice (ECLJ) and Alliance Defending Freedom (ADF), two countersecularist NGOs active at European and international level. These international conservative organizations have increasingly been involved in legal proceedings important for Romanian religion-related mobilizations (most recently, on the constitutional change of the definition of "marriage" and on the latest Coman case mentioned above). Moreover, Romanianspeaking jurists from these two international NGOs have come to participate in debates in the national public sphere. ${ }^{30}$ Even more notably, an increasing variety of counter-secularist actors have come to make use of human rights documents and to reference the Court as visible, at present, in televised debates.

For example, on June 3, 2017, the national television channel TVR 1 aired a show titled "Appeal to Morals" (Rom. "Apel la morală") on the mobilization to change the Constitution. A lawyer and spokesperson from APOR, the NGO bringing together "parents for the 'Religion' class", which joined the 2015 citizen mobilization platform targeting the constitutional definition of "marriage", defended the position of her mobilization camp by, among others, referencing the Strasbourg Court and its case law. In the debate, this activist responded to an LGBT rights supporter in the following way:

I will respond to you, and I respond with reference to the European Court of Human Rights [...] [which] in a constant jurisprudence-constant, from ... the oldest I can remember [now] is the case Karner versus Austria, but there are also older [cases], until the last [judgement] of the Court of Justice of the European Union from November $24^{\text {th }}, 2016$-all the European jurisprudence has a red thread, both of the European Court of Human Rights, and of 
the Court of Justice [of the European Union], and it says the same thing: to define marriage is the exclusive attribute of the member state.

Such a position-taking is not exceptional at present in the countersecularist camp, where not only jurists but also actors with other qualifications (e.g., an actress, a journalist) ${ }^{31}$ have entered public debates armed with legal pronouncements, including from human rights treaties and the case law of the Court.

The references to the Court's case law made in public debates are sometimes "ornamental", meaning that the doctrinal content of the referenced decision does not necessarily support the particular argument being made. The Karner reference above is perhaps a good example.

From the perspective of LGBT rights supporters, counter-secularist activists "misuse" the jurisprudence of the Court. As some emphasized to us, ${ }^{32}$ the counter-secularists ignore the most recent developments of the jurisprudence and cite outdated cases, preferentially select Court pronouncements and take them out of context, or even distort the content of the pronouncements. Of course, most of these imputed practices pertain to the array of argumentative strategies commonly encountered among lawyers. In any case, such observations support Fraser's (1990) point about discursive practices in the public sphere being competitive practices that follow the logic of the accumulation of symbolic capital ("distinction"), and deviating from the Habermasian communicative ideal.

From a different viewpoint, one may also read the inter-linked processes presented in this section as augmenting the secularization of discourse in the public sphere, as policy claims grounded in religious belief become "translated" (Habermas 2008) through the use of the Court's case law (and other international legal documents) into claims formulated in juridical language.

\section{CONCLUSIONS}

To conclude, we return to the main question raised by the contributions in this symposium, namely, to what extent is it possible to discern a "shadow" of the European Court over the social mobilizations concerning religion's place in education in present-day Romania. As we have shown, the Court has been perceived as a component of the relevant opportunity structure and has been approached by Romanian secularist activists as a forum for the pursuit of their agendas. In addition, the jurisprudence of 
the Court features in public debates, suggesting that the "indirect" or "radiating" effects of the Court's case law should be also sought beyond the juridical field (compare, e.g., Koenig 2015).

The use of Court references in public debates in present-day Romania can be interpreted as illustrative of the importance of this "species of capital" (Bourdieu and Wacquant 1992) within the tension-fraught national public sphere (Fraser 1990). Such practices are likely to reinforce the perception of the Court as a component of the "political opportunity structure" (Koopmans 1999) relevant for (counter-)secularist mobilizations in Romania. Last but not least, this logic of discursive conflict within the public sphere presses activists to "translate" (Habermas 2008) claims grounded in religious belief into the secular language of legal argumentation.

As our examples indicated, the invocation of the Court in public debates follows from a variable combination of developments in its reasoning and the usefulness of its (recent or older) pronouncements for activists' agendas. The clash of arguments at the present time is generated within discursive dynamics growing out of both national and transnational activism. These findings support the idea of "de-centering" (Galanter 1983) the analysis of the Court's relevance for religion-related mobilizations away from the doctrinal content of the decisions and closer to the actual uses that (counter-) secularist activists make of them, both within and beyond the legal arena.

\section{Supplementary Material}

The supplementary material for this article can be found at https://doi.org/ $10.1017 /$ S1755048318000068.

\section{NOTES}

1. This analysis is based on data generated in the Grassrootsmobilise research program funded by the European Research Council (GA No. 338463). The authors thank their colleagues from the Grassrootsmobilise team, Nicholas Tampio, as well as two anonymous reviewers for their useful comments on the manuscript. The first author additionally acknowledges the support granted by the Centre for Citizenship, Social Pluralism and Religious Diversity at the University of Potsdam through a visiting research fellowship during which parts of this analysis have been developed.

2. See this symposium's introductory text for a broad definition of the notion of 'mobilization' as employed here.

3. For instance, in 2016, Romania ranked fifth out of 47 member states in the Council of Europe in the number of pending cases, and had already been found in violation of at least one article of the European Convention on Human Rights in over 1,100 cases since its ratification of the treaty in 1994. See the various statistical reports on the ECtHR website, particularly http://www.echr.coe.int/ Documents/Facts_Figures_2016_ENG.pdf and http://www.echr.coe.int/Documents/Stats_violation_ 1959_2016_ENG.pdf, accessed January 5, 2018. 
4. No less than $89 \%$ of respondents in a national survey carried out in 2015 declared they heard about the Court, and $71 \%$ stated they trusted it highly. Survey report available at http://www.dreptur icivile.ro/wp-content/uploads/docs/APADOR_Studiu_sociologic_Drepturile_omului.pdf, accessed June 30, 2017.

5. Fifty-seven percent of Romanians trust the EU compared with a $42 \%$ average in the EU-28, according to the 2017 Eurobarometer (available at http://ec.europa.eu/commfrontoffice/publicopin ion/index.cfm/ResultDoc/download/DocumentKy/79118, accessed November 22, 2017).

6. The Appendix is available online at http://grassrootsmobilise.eu/wp-content/uploads/2018/01/ Religion-and-Education-in-Romania_Appendix.pdf and at https://perma.cc/8FP8-8LH3.

7. Mandatory courses on ECtHR jurisprudence are absent from law schools' undergraduate curricula. This situation was indicated as a shortcoming by several interviewees involved in human rights litigation (interviews 1 and 6 in Table 1 in the Appendix).

8. Interviews $1,4,6,8,9,10,14,18,20,23,24,25,37,46$.

9. Interviews $22,27,29$.

10. Interviews $5,12,13,16,19,38$.

11. The private education sector is underdeveloped in Romania, except for kindergartens and universities. It consists mainly of several dozen upper secondary and high schools, falling into two major classes: competitive schools targeting the children of the well-to-do; and (non-theological) confessional schools and high schools.

12. Document available at https://www.osce.org/odihr/29154?download=true, accessed December 16, 2017.

13. In Romania, Law 489/2006 on Religious Freedom and Religious Denominations distinguishes between three types of religious communities, which benefit from different levels of state recognition and support: 'religious denominations' (Rom. culte), 'religious associations' (Rom. asociatii religioase), and 'religious groups' (Rom. grupuri religioase) (see Andreescu 2008, Popa and Andreescu 2017 for analyses of these legal categories' implications for religious freedom).

14. Interview 38.

15. The Greek Catholic Church may represent one of the partial exceptions to this trend: the only RE case which reached the ECtHR from Romania (Jula v. Romania, pending) arose from this religious community. The case is centered on the complaint that the law discriminates against minority Greek Catholics by setting a high numerical threshold (seven pupils) for the organization of a study group.

16. Interview 2.

17. See, for instance, Cernea's comment on the Court's "historical decision" regarding the legal protection of same-sex couples in Oliari and Others v. Italy (2015), and on the Court's case law more generally as "mandatory for all member states of the Council of Europe, thus also for Romania" (available (in Romanian) at http://voxpublica.realitatea.net/politica-societate/decizie-istorica-a-curtii-europene-a-drepturilor-omului-care-obliga-statul-sa-recunoasca-parteneriatul-civil-sisaucasatoria-per soanelor-de-acelasi-sex-113476.html, accessed December 7, 2017).

18. See, e.g., the anti-discrimination Council's Decision no. 279/2007 judging a textbook for the Orthodox 'Religion' class to infringe anti-discrimination legislation because it presented several minority religions in deprecatory terms.

19. Decision no. 323/2006, on file with the authors.

20. See the intervention of ProVita-Bucharest at the Court after the Chamber decision asking for the case to be referred to the Grand Chamber, available (in Romanian) at http://provitabucuresti.ro/activi tati/just/298-lautsi-vs-italia-cedo, accessed December 2, 2017. The Lautsi case became notorious in the Romanian public sphere, coming as it did immediately after the heated icons debate. The Grand Chamber decision was met with approval by the Orthodox Church and Orthodox civil society organizations. In contrast, it may have demobilized some secularist actors. Our interviewee from the anti-discrimination Council considered the decision to have been no less than "a slap in the face" for his institution.

21. See, for instance, the analysis of Gregor Puppinck (the Director General of the European Center for Law and Justice) concerning "abortion in European law" (including the Court's case law) available (in Romanian translation) at http:/www.culturavietii.ro/2016/06/20/avortul-legislatia-europeana-noustudiu/, accessed December 7, 2017.

22. See, for instance, the open letter from June 12, 2015 submitted by ASUR and other NGOs to the Ministry of Education asking for the laying off of a ministerial counselor, a founding member of 
the parents' association APOR, for an alleged religious bias against mandatory sex education (available (in Romanian) at http://www.asur.ro/solicitare-catre-ministerul-educatiei-nationale/, accessed December 3, 2017).

23. See, for instance, the open letter from June 11, 2015 asking the Minister of Education and the Minister of Health to promote abstinence until marriage in public schools, available (in Romanian) at http://www.revista22.ro/asociatia-parinti-pentru-ora-de-religie-cere-ministrilor-educatiei-si-sanatatiialaturi-de-alte-19-ong--uri-sa-promoveze-in-scoli-abstinenta-pana-la-casatorie-56634.html, accessed December 3, 2017.

24. See, e.g., the open letter cited above (n. 23).

25. See, e.g., the open letter cited above (n. 22).

26. For a description of the case, see http://eulawanalysis.blogspot.de/2017/03/awaiting-ecj-judg ment-in-coman-towards.html, accessed December 7, 2017.

27. Especially interviews 1, 4, 6, 8, 14, 20, 24, 25, 46.

28. In the television show "Jocuri de putere" (Eng. "Power Games") aired by Realitatea TV on March 5, 2015, Moise responded in this way to the remarks of a constitutional law professor close to the counter-secularist camp, who had just questioned Moise's juridical expertise. A philosophy teacher, Moise gathered juridical expertise directly through litigation in his own name and that of his association, even before graduating a study program in law.

29. See the public intervention of philosopher Horia Roman Patapievici in response to the antidiscrimination Council's decision asking for the removal of Orthodox icons from public schools, available (in Romanian) at http://inliniedreapta.net/dereferinta/horia-roman-patapievici-legitimareaanticrestinismului-prin-redefinirea-centrului/, accessed December 8, 2017.

30. See, for instance, the comments on the Court's case law by ECLJ jurist Andreea Popescu, on the conservative forum În Linie Dreaptă (Eng. The Right Line, http://inliniedreapta.net); and the contributions of ADF legal counsel Adina Portaru to the pro-life blog Cultura Vietiii (Eng. Culture of Life, www.culturavietii.ro).

31. See the examples discussed by the first author in an intermediary research contribution published online at http://grassrootsmobilise.eu/7-romania-picking-up-the-white-glove-juridical-argu ments-in-contentious-discourse-concerning-the-legal-recognition-of-same-sex-couples-in-romania/, accessed December 1, 2017.

32. Interviews 25,46 .

\section{REFERENCES}

Andreescu, Liviu. 2008. "Romania's New Law on Religious Freedom and Religious Denominations." Religion, State and Society 36(2):139-161.

Bob, Clifford. 2012. The Global Right Wing and the Clash of World Politics. New York: Cambridge University Press.

Bourdieu, Pierre. 1977. "The Force of Law: Toward a Sociology of the Juridical Field." The Hastings Law Journal 38:805-853.

Bourdieu, Pierre, and Loïc J.D. Wacquant. 1992. An Invitation to Reflexive Sociology. Cambridge: Polity Press.

Byrnes, Timothy A., and Peter J. Katzenstein. eds. 2006. Religion in an Expanding Europe. Cambridge: Cambridge University Press.

Calhoun, Craig. 2010. "The Public Sphere in the Field of Power." Social Science History 34(3):301-335.

Durham, Jr., Cole W., and David M. Kirkham. 2016. "Introduction." In Islam, Europe and Emerging Legal Issues, eds. W. Cole Jr.Durham, Rik Torfs, David M. Kirkham and Christine Scott. Abington: Routledge, 1-17.

Enache, Smaranda. ed. 2007. Educația Religioasă în S,colile Publice [Religious Education in Public Schools]. Târgu-Mureș: Pro Europa.

Evans, Malcolm, and Peter Petkoff. 2008. "A Separation of Convenience? The Concept of Neutrality in the Jurisprudence of the European Court of Human Rights." Religion, State and Society 36(3):205-223. 
Fligstein, Neil, and Doug McAdam. 2011. "Toward a General Theory of Strategic Action Fields." Sociological Theory 29(1):1-26.

Fokas, Effie. 2015. "Directions in Religious Pluralism in Europe: Mobilizations in the Shadow of European Court of Human Rights Religious Freedom Jurisprudence." Oxford Journal of Law and Religion 4(1):54-74.

Fraser, Nancy. 1990. "Rethinking the Public Sphere: A Contribution to the Critique of Actually Existing Democracy." Social Text 25/26:56-80.

Galanter, Marc. 1983. "The Radiating Effects of Courts." In Empirical Theories About Courts, eds. Keith O. Boyum and Lynn M. Mather. New York: Longman, $117-142$.

Gülalp, Haldun. 2010. "Secularism and the European Court of Human Rights." European Public Law 16(3):455-471.

Habermas, Jürgen. [1962] 1991. The Structural Transformation of the Public Sphere: An Inquiry into a Category of Bourgeois Society. Cambridge, MA: MIT Press.

Habermas, Jürgen. 2008. Between Naturalism and Religion. Cambridge: Polity Press.

Jackson, Robert. 1992. "The Misrepresentation of Religious Education." In Ethics, Ethnicity and Education, eds. M. Leicester and M. Taylor. London: Kogan Page, 100-113.

Karpov, Vyacheslav. 2010. "Desecularization: A Conceptual Framework." Journal of Church and State 52(2):232-270.

Kligman, Gail. 1998. The Politics of Duplicity: Controlling Reproduction in Ceausescu's Romania. Berkeley, CA: University of California Press.

Koenig, Matthias. 2015. "The Governance of Religious Diversity at the European Court of Human Rights." In International Approaches to Governing Ethnic Diversity, eds. Jane Boulden and Will Kymlicka. Oxford: Oxford University Press, 51-78.

Koopmans, Ruud. 1999. "Political. Opportunity. Structure. Some Splitting to Balance the Lumping." Sociological Forum 14:93-105.

Lisovskaya, Elena. 2016. "Religious Education in Russia. Inter-Faith Harmony or NeoImperial Toleration?." Social Inclusion 4(2):117-132.

Lisovskaya, Elena, and Vyacheslav Karpov. 2010. "Orthodoxy, Islam, and the Desecularization of Russia's State Schools." Politics and Religion 3(2):276-302.

Madsen, Mikael Rask. 2007. "From Cold War Instrument to Supreme European Court: The European Court of Human Rights at the Crossroads of International and National Law and Politics." Law \& Social Inquiry 32(1):137-159.

Mancini, Susanna. 2009. "The Power of Symbols and Symbols as Power: Secularism and Religion as Guarantors of Cultural Convergence." Cardozo Law Review 30(3):2629_ 2668.

McCann, Michael. 2004. "Law and Social Movements." In The Blackwell Companion to Law and Society, ed. Austin Sarat. Malden, MA: Blackwell, 506-522.

Meyer, David S., and Suzanne Staggenborg. 1996. "Movements, Countermovements, and the Structure of Political Opportunity.” The American Journal of Sociology 101(6):16281660.

Patton, Michael Quinn. 2001. "Purposeful Sampling.” In Ethnography. Vol. 2, ed. Alan Bryman. London: Sage, 106-121.

Popa, Mihai, and Liviu Andreescu. 2017. "Legal Provisions, Courts, and the Status of Religious Communities: A Socio-Legal Analysis of Inter-Religious Relations in Romania." Religion, State and Society 45(3-4):297-316.

Ringelheim, Julie. 2017. "State Religious Neutrality as a Common European Standard? Reappraising the European Court of Human Rights Approach." Oxford Journal of Law and Religion 6(1):24-47. 
Romocea, Cristian. 2011. "Church-State Relations in Post-1989 Romania." Journal of Church and State 53(2):243-277.

Sampson, Steven. 1996. "The Social Life of Projects: Importing Civil Society to Albania." In Civil Society: Challenging Western Models, eds. Elizabeth Dunn and Chris Hann. London \& New York: Routledge, 119-140.

Smith, Christian. 2003. "Introduction: Rethinking the Secularization of American Public Life." In The Secular Revolution: Power, Interests, and Conflict in the Secularization of American Public Life, ed. Christian Smith. Berkeley, CA: University of California Press, 1-96.

Stan, Lavinia, and Lucian Turcescu. 2005. "Religion, Politics and Sexuality in Romania." Europe-Asia Studies 57(2):291-310.

Stan, Lavinia, and Lucian Turcescu. 2007. Religion and Politics in Post-Communist Romania. New York: Oxford University Press.

Stychin, Carl F. 2003. Governing Sexuality: The Changing Politics of Citizenship and Law Reform. Oxford \& Portland, OR: Hart Publishing. 